\title{
Analysis of Microsatellite Loci for Swimming Crab Portunus trituberculatus Populations in the Korean Side of the Yellow Sea
}

Hye Jin Lee ${ }^{1,2}$, Seong Jong Yoon ${ }^{3}$, Young Se Hyun', Hye Jin Kim', Sung-ll Hwang', Joo-Seung Bae and Ki Wha Chung ${ }^{1}$.

\author{
${ }^{1}$ Department of Biological Science, Kongiu National University, Chungnam 314-701, Korea \\ ${ }^{2}$ Division of DNA Analysis, Criminal Investigation Command, Ministry of National Defense, Seoul 140-701, Korea \\ ${ }^{3}$ Korea Fisheries Resources Agency, Busan 612-020, Korea \\ ${ }^{4}$ Underwater Ecology Institute, Jeannam 550-833, Korea \\ ${ }^{5}$ Fishery Division, Incheon Metropolitan City, Incheeon 405-750, Korea
}

Received September 5, 2013 /Revised September 24, 2013 /Accepted September 25, 2013

\begin{abstract}
The swimming crab, Portunus trituberculatus, inhabits seafloor habitats containing sand or pebbles and is widely distributed throughout the world. The present study investigated genetic polymorphisms of 10 microsatellites in 281 samples of $P$. trituberculatus collected from four locations along the coastal water of the Korean side of the Yellow Sea (Yeonggwang, Taean, Sorea, and Yeonpyeong-do Island). The number of alleles per locus ranged from 50 to 129, with a mean of 69.5. The observed and expected hetrozygosity varied from 0.111 to 1.000 and from 0.609 to 0.979 , respectively. The inbreeding coefficients (Fis) varied among the loci from -0.0207 to 0.8175 . The genetic differentiation (Fst) was less than 0.05 (range 0.0020-0.0124). Therefore, the four groups of $P$. trituberculatus appeared to exhibit little genetic differentiation. The lack of differentiation was confirmed in a phylogenetic tree constructed by the unweighted pair group method with the arithmetic average (UPGMA). The hypervariation between the populations and the lack of genetic differentiation may reflect active gene flow among the Yellow Sea populations and the absence of geographical boundaries. The highly polymorphic microsatellite loci will be useful for molecular and phylogenetic studies, as well as stock management, of swimming crab, which is an important fishery resource.
\end{abstract}

Key words : Microsatellite, polymorphism, Portunus trituberculatus, swimming crab, Yellow Sea

\section{Introduction}

The swimming crab, Portunus trituberculatus (Crustacea: Decapoda: Brachyura) belongs to the crustacean brachyuran species, which inhabit both seawater and freshwater worldwide, comprising about 6,000 species [3]. P. trituberculatus is distributed in coastal waters of East Asia with sand or pebble habitats. Because $P$. trituberculatus is one of the most common edible crab species in East Asia, it is considered to be a commercially important fishery resource. Thus, there have been performed considerable efforts to increase the aquacultural yield of $P$. trituberculatus by artificial propagation and the release of young swimming crabs.

\footnotetext{
*Corresponding author

Tel : +82-41-850-8506, Fax : +82-41-850-0957

E-mail : kwchung@kongju.ac.kr

This is an Open-Access article distributed under the terms of the Creative Commons Attribution Non-Commercial License (http://creativecommons.org/licenses/by-nc/3.0) which permits unrestricted non-commercial use, distribution, and reproduction in any medium, provided the original work is properly cited.
}

Based on the analyses of mitochondrial DNA (mtDNA), several molecular approaches have been taken to understand the population genetic structures of $P$. trituberculatus. Imai et al [9] investigated the restriction fragment length polymorphisms (RFLP) in the whole mtDNA of Japanese samples. Liu et al [11] and $\mathrm{Xu}$ et al [23] studied the genetic differentiation among geographical populations captured from several coastal areas of China, based on the mitochondrial 16S rDNA and cytochrome c oxidase subunit 1 (COI) genes. Particularly, Cho et al [5] performed the phylogenetic analysis using haplotypes of the mtDNA control region in subject with $P$. trituberculatus collected in the Korean coastal area of the Yellow Sea. However, these mtDNA markers have been shown to have some restriction in application to the various studies of phylogenetic analysis, molecular breeding and individual identification and forensics. Therefore, more effective molecular markers for population genetic studies are required.

Microsatellites, also called short tandem repeats (STRs), have been regarded to be effective molecular markers for population genetic study due to their high level of in- 
formativity and wide distributions in the genome $[7,20]$. Microsatellites have been widely applied for chromosomal mapping and identification of quantitative trait loci $[18,19]$, phylogenic study [8], and forensic application $[2,12,25]$ as well as fishery study [1]. Microsatellites have characteristics of co-dominant and multiallelic inheritance. Microsatellites in $P$. trituberculatus have very recently been studied in samples collected from the East China Sea [6, 24] and the Yellow Sea in Korea [10].

Because of their phylogeographic distribution and importance as a fishery resource in East Asia, the determination of population genetic structure in $P$. trituberculatus is important. Most molecular genetic studies for $P$. trituberculatus have been performed in samples collected from coastal waters near the China and Japan. However, little phylogenetic study has been performed in crabs from Korean coastal water, although genetic polymorphisms of mtDNA [5] and microsatellites [10] have been studied in samples from the Yellow Sea.

In the present study, we identified many microsatellite motifs from P. trituberculatus genome, and 10 markers (PS27, PS108, PS247, PS260, PS385, PS747, PS756, PS400, PS703, and PS704) were analyzed for their genetic variation and population genetic structure among four populations collected from coastal waters of the Yellow Sea in Korea.

\section{Materials and Methods}

Sample collection and extraction of genomic DNA

Samples of $P$. trituberculatus $(\mathrm{n}=281)$ were collected from four locations along the coastal water of the Korean side of the Yellow Sea: Yeonggwang (Jeonnam, n=83), Taean (Chungnam, n=93), Sorea (Incheon, $\mathrm{n}=78$ ), and Yeonpyeongdo Island (Incheon, n=27) during June to October, 2010 (Fig. 1). Crab tissues (usually leg muscle) were disrupted by a TissueLyser II (Qiagen, Hilden, Germany), and then used for genomic DNA purification. DNA was purified using a QIAamp DNA Micro kit (Qiagen, Hilden, Germany). The purified DNA was quantified by a spectrophotometer (Smart Spec 3000, BIO-RAD, USA) and stored at $-20^{\circ} \mathrm{C}$ until use.

\section{Preparation of locus-specific primers}

The flanking sequences of DNA fragments with the microsatellite repeat motifs were used to design locus-specific primers. The primer pairs were designed according to the following criteria by using the PRIMER 3 program (ver. 0.4.0, http://fokker.wi.mit.edu/primer3/): length, 20-26 bp; melting temperature, $55^{\circ} \mathrm{C}$ or higher, and PCR product size,

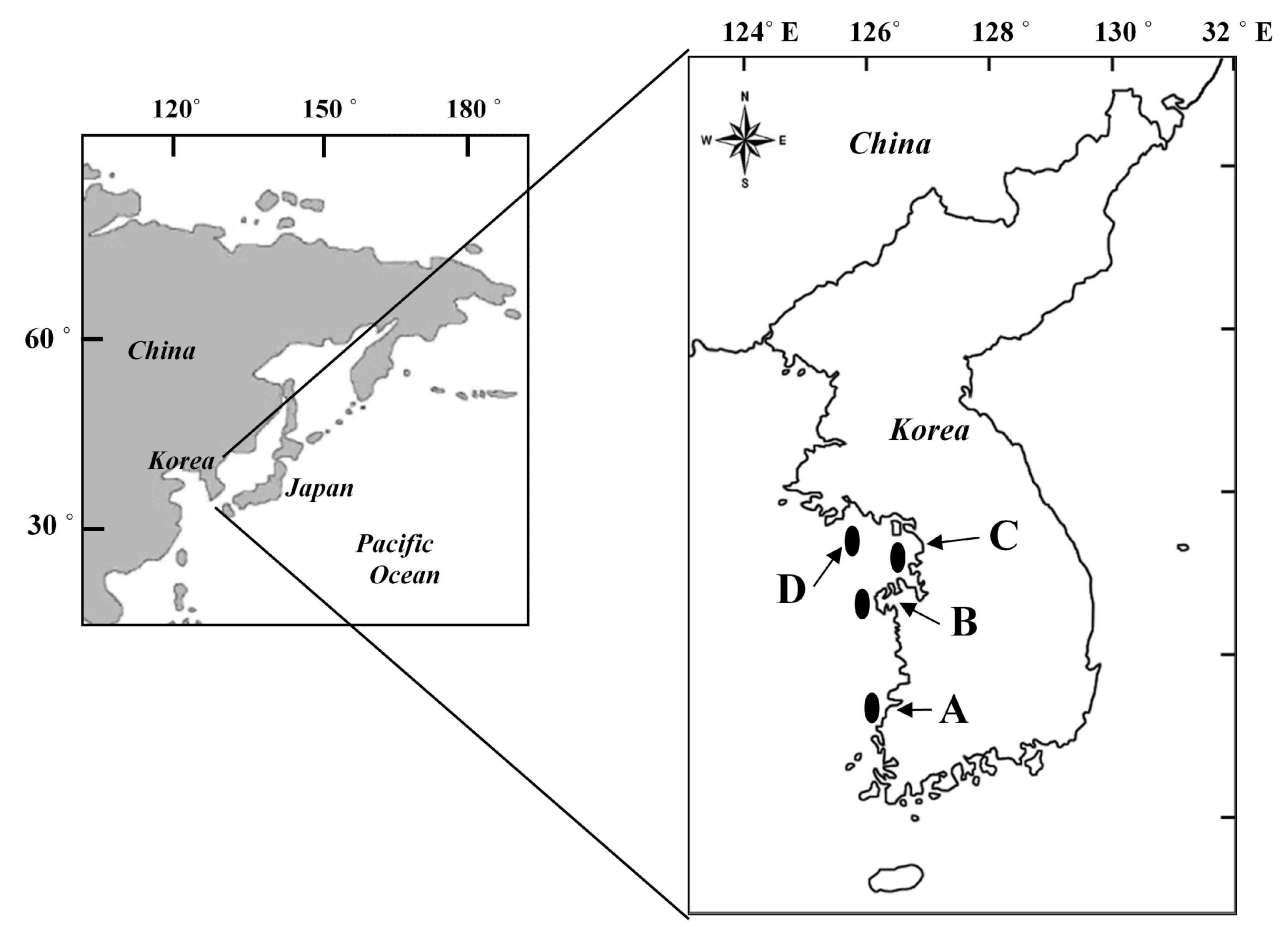

Fig. 1. Sampling locations of swimming crab, P. trituberculatus. Swimming crabs were collected from four sites along the coast of the Yellow Sea in Korea: Yeonggwang (A), Taean (B), Sorea (C), and Yeonpyeong-do Island (D) during June to October, 2010. 
100 - 350 bp. Particularly, all forward primers (designated as M13F-forward primer) were prepared to have M13 universal primer sequence at the $5^{\prime}$-upstream of locus-specific sequence ( $5^{\prime}$-TGTAAAACGACGGCCAGT-locus specific forward primer- $\left.3^{\prime}\right)$.

\section{PCR and genotyping of microsatellites}

PCR was performed as described by Schuelke [16] with minor modifications. The reaction mixture contained 0.25 pmol of reverse primer, 1 pmol of each M13F-forward primer and FAM-labeled M13F primer (FAM-5'-TGTAAAACGACGGCCAGT-3'), 10-20 ng of genomic DNA, 0.25 unit of AmpliTaq Gold polymerase (Applied Biosystems, Foster City, CA, USA) and 1X buffer with dNTPs in a total volume of $10 \mu \mathrm{l}$. Thermal cycling was conducted on a PTC-200 DNA engine (MJ Research, Waltham, MA) using the following condition: $95^{\circ} \mathrm{C}$ for $11 \mathrm{~min}, 20$ cycles of $95^{\circ} \mathrm{C}$ for $30 \mathrm{~s} ; 45$ $\mathrm{s}$ at a given annealing temperature for each marker; $72^{\circ} \mathrm{C}$ for $1 \mathrm{~min}, 15$ cycles of $95^{\circ} \mathrm{C}$ for $30 \mathrm{~s} ; 45 \mathrm{~s}$ at $53^{\circ} \mathrm{C} ; 72^{\circ} \mathrm{C}$ for $1 \mathrm{~min}$ with a final elongation of $68^{\circ} \mathrm{C}$ for $60 \mathrm{~min}$. Primer sequences, GenBank accession number, annealing temperature and repeat unit of each locus are listed in Table 1. Each PCR product was separated by an ABI 3100 genetic analyzer (Applied Biosystems). The Liz-500 was used for internal standard. Genotypes were determined using the Genotyper program, ver. 3.7 (Applied Biosystems). The nucleotide sequences for microsatellite markers were determined by using a Chromas program, ver. 2.33 (Technelysium Pty, Australia).

\section{Statistical analyses}

Allele frequencies were calculated from the observed genotypes. Genotyping errors (i.e. null alleles, stuttering and large allele dropout) which can cause deviations from Hardy-Weinberg proportions were determined using MICRO-CHECKER version 2.2.3 software [21]. Corrections of the significance level for multiple tests were adjusted using the Bonferroni procedure [13]. The diversity statistics (observed and expected heterozygosities), the Hardy-Weinberg equilibrium (HWE) for each locus, tests for genotypic linkage disequilibrium, the inbreeding coefficient (Fis) per locus and sample [22], and assessments of multi-locus Fst values were carried out using GENEPOP software, ver. 4.0 [15]. A phylogenetic dendrogram using allele frequencies was constructed by the unweighted pair group method with arithmetic average (UPGMA) with the SAHN module of

Table 1. Primer sequences, annealing temperatures and allelic structures of the polymorphic microsatellite markers in $P$. trituberculatus

\begin{tabular}{|c|c|c|c|c|c|c|}
\hline Locus & $\begin{array}{l}\text { GenBank } \\
\text { Acc. No. }\end{array}$ & Primer sequence $\left(5^{\prime}-3^{\prime}\right)^{\mathrm{a}}$ & $\mathrm{Tm} .\left({ }^{\circ} \mathrm{C}\right)$ & Size (bp) & Allele No. ${ }^{b}$ & $\begin{array}{c}\text { Repeat } \\
\text { motif }\end{array}$ \\
\hline PS27 & JN803923 & $\begin{array}{l}\text { AGGTGTTATGATAAGCAGGAAGG } \\
\text { ССТССТСТСССТTСТCAATTC }\end{array}$ & 60 & 211-339 & 70 & $\begin{array}{l}(\mathrm{AGT}) \mathrm{n} \\
(\mathrm{AGT}) \mathrm{n}\end{array}$ \\
\hline PS108 & JN803925 & $\begin{array}{l}\text { TCAACACTAAGAACGCTGAGGA } \\
\text { TTGACTGTTTCTGCTACTAGGTTTTC }\end{array}$ & 55 & $99-326$ & 129 & $\begin{array}{l}(\mathrm{AAG}) \mathrm{n} \\
(\mathrm{AAG}) \mathrm{n}\end{array}$ \\
\hline PS247 & JN803926 & $\begin{array}{l}\text { TCCTACCCTGCCCTACCTTAC } \\
\text { ACTCTCCAGGCTTACACACCA }\end{array}$ & 60 & $109-211$ & 50 & $\begin{array}{l}(\mathrm{AG}) \mathrm{n} \\
(\mathrm{AG}) \mathrm{n}\end{array}$ \\
\hline PS260 & JN607375 & $\begin{array}{l}\text { GCACGAGAGAAAGACGAA } \\
\text { AGTGAGGGATGGTGATTATAAG }\end{array}$ & 60 & $99-203$ & 55 & $\begin{array}{l}(\mathrm{AC}) \mathrm{n} \\
(\mathrm{AC}) \mathrm{n}\end{array}$ \\
\hline PS385 & JN607395 & $\begin{array}{l}\text { CATCTTTAAAAACCCGTGTGC } \\
\text { AATTTTCCCAGTCGTTGTCCT }\end{array}$ & 60 & $118-198$ & 52 & $\begin{array}{l}(\mathrm{AG}) \mathrm{n} \\
(\mathrm{AG}) \mathrm{n}\end{array}$ \\
\hline PS747 & JN803933 & $\begin{array}{l}\text { CCGCTGAATCGTTATTGAATG } \\
\text { CCATAGGCCCTTCCTAATGTG }\end{array}$ & 60 & $117-252$ & 64 & $\begin{array}{l}(\mathrm{AG}) \mathrm{n} \\
(\mathrm{AG}) \mathrm{n}\end{array}$ \\
\hline PS756 & JN803934 & $\begin{array}{l}\text { CTGGGGAAATCCTAATGGTGT } \\
\text { TCСТTTCATTCTCССТССАСТ }\end{array}$ & 60 & $169-220$ & 51 & $\begin{array}{l}(\mathrm{AG}) \mathrm{n} \\
(\mathrm{AG}) \mathrm{n}\end{array}$ \\
\hline PS400 & JN803927 & $\begin{array}{l}\text { GTCGAGCGTGCTAACCACTAC } \\
\text { GCGGCATGTAATATTGAGGAA }\end{array}$ & 60 & $121-223$ & 75 & $\begin{array}{l}(\mathrm{AC}) \mathrm{n} \\
(\mathrm{AC}) \mathrm{n}\end{array}$ \\
\hline PS703 & JN803930 & $\begin{array}{l}\text { AGATAGGGAGGACAAGGAGAAG } \\
\text { CTGTGTAGCACCTGTCTTGCT }\end{array}$ & 60 & $111-220$ & 72 & $\begin{array}{l}(\mathrm{AG}) \mathrm{n} \\
(\mathrm{AG}) \mathrm{n}\end{array}$ \\
\hline PS704 & JN803931 & $\begin{array}{l}\text { CGCACAGGGATTAATGCATAC } \\
\text { TCGCAAAATTCAGGTTACTGC }\end{array}$ & 60 & $148-240$ & 77 & $\begin{array}{l}(\mathrm{AG}) \mathrm{n} \\
(\mathrm{AG}) \mathrm{n}\end{array}$ \\
\hline
\end{tabular}

${ }^{\mathrm{a}}$ Forward primers represent only locus-specific sequence (5'-M13 sequence was not shown).

${ }^{\mathrm{b}}$ Observed allele numbers were obtained from 281 samples collected from 4 different localities. 
NTSYS-pc, ver. 2.1 [14]. The gene diversity (GD) was determined using the formula $G D=n\left(1-\sum P_{i}^{2}\right) /(n-1)$, where $n$ represents the number of samples, and $\mathrm{Pi}$ is the allele frequencies in a given population sample. The polymorphism information content (PIC), power of exclusion (PE), and power of discrimination (PD) were calculated by the PowerStatsV12 program (Promega, Madison, WI, USA).

\section{Results}

Isolation of polymorphic microsatellite loci

We have previously identified 684 microsatellite motifs from the $P$. trituberculatus genome [10]. From the isolated microsatellite motifs, 87 locus-specific primer pairs were prepared and used for PCR amplification and genotyping on the genome of $P$. trituberculatus. PCR amplification was distinctly achieved at 60 primer sets, however, 27 primer pairs failed to obtain a clear PCR product or genotyping result from the PCR product. Genotyping of 60 loci revealed that 52 loci were polymorphic from 30 P. trituberculatus samples collected from the Korean side of the Yellow Sea (86.7\%), whereas 8 loci showed monomorphic. Most polymorphic loci were determined to be highly informative. Forty four loci exhibited observed allele numbers of 10 or more. Moreover, 11 loci showed more than 30 alleles.

\section{Population genetic study}

From the polymorphic loci, 10 loci (PS27, PS108, PS247, PS260, PS385, PS747, PS756, PS400, PS703, and PS704) were chosen, and were examined for their polymorphism and phylogenetic analysis of $P$. trituberculatus populations. We analyzed a total of $281 P$. trituberculatus samples collected from the west side of Korea including Yeonggwang (WOJ, $\mathrm{n}=83$ ), Taean (WOT, $\mathrm{n}=93$ ), Sorea (WOP, $\mathrm{n}=78$ ), and Yeonpyeong-do Island (WOY, n=27) (Fig. 1).

The genotyping results revealed that all the populations of $P$. trituberculatus were highly polymorphic with a total observed allele number of 695 . The number of alleles per locus ranged from 50 (PS247) to 129 (PS108) with a mean number of 69.5 (Table 1). The observed and expected heterozygosities varied from 0.111 to 1.000 and from 0.609 to 0.979 , respectively. Significant deviations of the Hardy-Weinberg

Table 2. Summary of variation across 10 microsatellite loci in swimming crab ( $P$. trituberculatus) from four natural populations

\begin{tabular}{|c|c|c|c|c|c|c|c|c|c|c|c|}
\hline \multirow{2}{*}{$\begin{array}{l}\text { Population } \\
\text { (n) })^{\mathrm{a}}\end{array}$} & \multirow{2}{*}{ Item $^{\mathrm{b}}$} & \multicolumn{10}{|c|}{ Microsatellite loci } \\
\hline & & PS27 & PS108 & PS247 & PS260 & PS385 & PS747 & PS756 & PS400 & PS703 & PS704 \\
\hline \multirow{5}{*}{$\begin{array}{l}\text { WOJ } \\
(n=83)\end{array}$} & $A$ & 45 & 77 & 39 & 36 & 43 & 49 & 31 & 47 & 43 & 51 \\
\hline & Ho & 0.7108 & 0.8675 & 0.8193 & 0.9759 & 0.8675 & 0.9036 & 0.8675 & 0.6747 & 0.7590 & 0.6265 \\
\hline & $H E$ & 0.8856 & 0.9793 & 0.9662 & 0.9561 & 0.9683 & 0.9684 & 0.9535 & 0.8096 & 0.8416 & 0.8233 \\
\hline & HWE & 0.0000 & 0.7658 & 0.0131 & 0.1099 & 0.1425 & 0.3204 & 0.0023 & 0.0949 & 0.0000 & 0.0000 \\
\hline & $F$ is & 0.1973 & 0.1142 & 0.1521 & -0.0207 & 0.1041 & 0.0669 & 0.0902 & 0.1666 & 0.0981 & 0.2390 \\
\hline \multirow{5}{*}{$\begin{array}{l}\text { WOT } \\
(n=93)\end{array}$} & $A$ & 48 & 69 & 40 & 33 & 37 & 40 & 37 & 50 & 43 & 54 \\
\hline & Ho & 0.7957 & 0.6774 & 0.5914 & 0.9247 & 0.8710 & 0.8817 & 0.8817 & 0.8925 & 0.9570 & 0.8710 \\
\hline & $H_{\mathrm{E}}$ & 0.9524 & 0.9602 & 0.8723 & 0.9543 & 0.9568 & 0.9376 & 0.9562 & 0.9385 & 0.9326 & 0.9154 \\
\hline & HWE & 0.0000 & 0.0000 & 0.0000 & 0.0157 & 0.0042 & 0.0000 & 0.0000 & 0.0032 & 0.2394 & 0.0709 \\
\hline & $F \mathrm{is}$ & 0.1645 & 0.2945 & 0.3220 & 0.0310 & 0.0897 & 0.0596 & 0.0779 & 0.0490 & -0.0262 & 0.0485 \\
\hline \multirow{5}{*}{$\begin{array}{c}\text { WOP } \\
(n=78)\end{array}$} & $A$ & 36 & 54 & 32 & 39 & 32 & 44 & 38 & 43 & 38 & 39 \\
\hline & Ho & 0.5513 & 0.5641 & 0.3718 & 0.8077 & 0.8974 & 0.7949 & 0.8205 & 0.5641 & 0.6410 & 0.5513 \\
\hline & $H_{E}$ & 0.8531 & 0.9587 & 0.9228 & 0.9548 & 0.9555 & 0.9591 & 0.9544 & 0.7485 & 0.7796 & 0.7821 \\
\hline & HWE & 0.0025 & 0.0000 & 0.0000 & 0.0000 & 0.0001 & 0.0052 & 0.0000 & 0.0000 & 0.0000 & 0.0004 \\
\hline & $F 1 \mathrm{~S}$ & 0.3538 & 0.4116 & 0.5971 & 0.1541 & 0.0608 & 0.1712 & 0.1403 & 0.2464 & 0.1778 & 0.2951 \\
\hline \multirow{6}{*}{$\begin{array}{l}\text { WOY } \\
(n=27)\end{array}$} & $A$ & 25 & 28 & 15 & 24 & 23 & 25 & 19 & 26 & 30 & 37 \\
\hline & Ho & 0.9259 & 0.4444 & 0.1111 & 0.8519 & 0.7407 & 0.7778 & 0.7407 & 1.0000 & 0.9259 & 0.9630 \\
\hline & $H E$ & 0.9580 & 0.9757 & 0.6088 & 0.9636 & 0.9636 & 0.9687 & 0.9181 & 0.9666 & 0.9751 & 0.9497 \\
\hline & HWE & 0.2784 & 0.0000 & 0.0000 & 0.0537 & 0.0182 & 0.0024 & 0.0102 & 0.4114 & 0.0607 & 0.0692 \\
\hline & $F \mathrm{is}$ & 0.0335 & 0.5445 & 0.8175 & 0.1160 & 0.2313 & 0.1971 & 0.1932 & -0.0346 & 0.0504 & -0.0140 \\
\hline & $F$ st & 0.0075 & 0.0042 & 0.0028 & 0.0041 & 0.0020 & 0.0027 & 0.0101 & 0.0062 & 0.0056 & 0.0124 \\
\hline
\end{tabular}

${ }^{a}$ Yeonggwang (WOJ), Taean (WOT), Sorea (WOP), and Yeonpyeong-do Island (WOY).

${ }^{\mathrm{b}}$ Number of alleles $(A)$, observed heterozygosity $\left(H_{b}\right)$, expected heterozygosity $\left(H_{\mathrm{E}}\right), P$-values for the Hardy-Weinberg equilibrium (HWE) tests, inbreeding coefficient $(F \mathrm{~s})$, and genetic differentiation between populations (Fst). 
equilibrium (HWE) were detected in three loci in Yeonggwang, five loci in Taean, eight loci in Sorea, and two loci in Yeonpyeong-do Island population (Table 2). The inbreeding coefficients (Fis) varied among loci from -0.0207 to 0.2390 in Yeonggwang, from -0.0262 to 0.3220 in Taean, from 0.0608 to 0.4116 in Sorea, and from -0.0346 to 0.8175 in the Yeonpyeong-do Island population (Table 2). In addition, linkage disequilibrium was revealed between six of the locus pairs (PS27 and PS385, PS260 and PS400, PS385 and PS400, PS747 and PS400, PS747 and PS704, PS756 and PS704) after Bonferroni correction ( $p<0.00357)$. We estimated the genetic differentiation ( $F$ st value) between these populations. From the results, the Fst over all samples per locus ranged from 0.0020 to $0.0124(p<0.05)$ (Table 2). The phylogenetic tree constructed by using the UPGMA also suggested that there is no significant genetic difference between Yeonggwang, Taean, Sorea, and Yeonpyeong-do Island populations (Fig. 2).

\section{Forensic analysis}

Several forensic parameters revealed that all the analyzed loci are highly useful for individual identification and paternity test (Table 3). High levels of gene diversity (GD) were calculated from all the loci ranging from 0.820 at PS108 (Taean) to 0.945 at PS260 and PS704 (Yeonpyeong-do Island). The power of exclusion (PE) and discrimination (PD) indexes

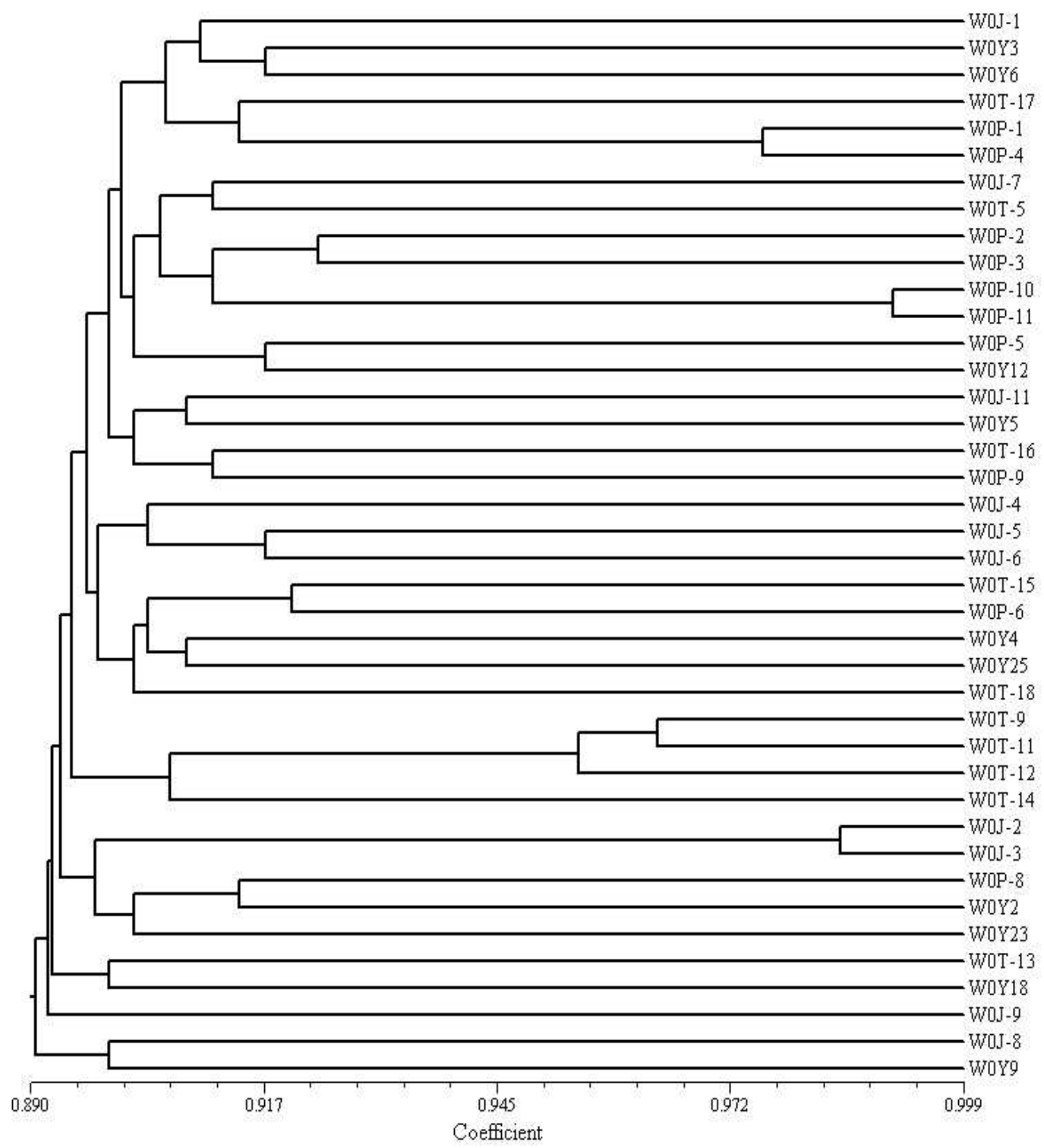

Fig. 2. Phylogenetic relationship of $40 \mathrm{P}$. trituberculatus samples based on the microsatellite marker typing. The dendrogram was constructed by the unweighted pair group method with arithmetic average (UPGMA). 
Table 3. Genetic diversity and forensic parameters of 10 microsatellite loci of $P$. trituberculatus

\begin{tabular}{|c|c|c|c|c|c|c|c|c|c|c|c|c|c|c|c|c|}
\hline \multirow{2}{*}{ Loci } & \multicolumn{4}{|c|}{$\mathrm{GD}^{\mathrm{a}}$} & \multicolumn{4}{|c|}{ PIC $^{b}$} & \multicolumn{4}{|c|}{$\mathrm{PE}^{\mathrm{c}}$} & \multicolumn{4}{|c|}{$\mathrm{PD}^{\mathrm{d}}$} \\
\hline & WOJ & WOT & WOP & WOY & WOJ & WOT & WOP & WOY & WOJ & WOT & WOP & WOY & WOJ & WOT & WOP & WOY \\
\hline PS27 & 0.857 & 0.860 & 0.837 & 0.883 & 0.850 & 0.850 & 0.820 & 0.880 & 0.188 & 0.795 & 0.114 & 0.795 & 0.900 & 0.900 & 0.860 & 0.900 \\
\hline PS108 & 0.925 & 0.820 & 0.885 & 0.900 & 0.920 & 0.800 & 0.870 & 0.890 & 1.000 & 0.188 & 0.599 & 0.114 & 0.860 & 0.840 & 0.880 & 0.880 \\
\hline PS247 & 0.895 & 0.880 & 0.870 & 0.860 & 0.890 & 0.870 & 0.860 & 0.840 & 0.428 & 0.599 & 0.188 & 0.000 & 0.880 & 0.840 & 0.860 & 0.860 \\
\hline PS260 & 0.900 & 0.890 & 0.885 & 0.945 & 0.890 & 0.880 & 0.880 & 0.940 & 1.000 & 1.000 & 0.188 & 1.000 & 0.880 & 0.880 & 0.860 & 0.900 \\
\hline PS385 & 0.900 & 0.895 & 0.870 & 0.930 & 0.890 & 0.890 & 0.860 & 0.930 & 0.795 & 1.000 & 0.795 & 0.795 & 0.880 & 0.840 & 0.880 & 0.900 \\
\hline PS747 & 0.895 & 0.875 & 0.910 & 0.895 & 0.890 & 0.860 & 0.900 & 0.890 & 0.795 & 0.599 & 0.599 & 0.428 & 0.880 & 0.820 & 0.860 & 0.880 \\
\hline PS756 & 0.830 & 0.910 & 0.850 & 0.880 & 0.810 & 0.900 & 0.840 & 0.870 & 0.599 & 0.599 & 0.795 & 0.291 & 0.880 & 0.900 & 0.860 & 0.880 \\
\hline PS400 & 0.915 & 0.920 & 0.895 & 0.920 & 0.910 & 0.910 & 0.890 & 0.910 & 1.000 & 1.000 & 0.795 & 1.000 & 0.880 & 0.880 & 0.880 & 0.900 \\
\hline PS703 & 0.895 & 0.895 & 0.900 & 0.890 & 0.890 & 0.890 & 0.890 & 0.880 & 0.795 & 1.000 & 0.795 & 0.795 & 0.840 & 0.900 & 0.880 & 0.900 \\
\hline PS704 & 0.925 & 0.858 & 0.900 & 0.945 & 0.920 & 0.840 & 0.890 & 0.940 & 1.000 & 1.000 & 0.599 & 1.000 & 0.900 & 0.815 & 0.880 & 0.900 \\
\hline Mean & 0.894 & 0.880 & 0.880 & 0,905 & 0.886 & 0.869 & 0.870 & 0.897 & 0.760 & 0.778 & 0.547 & 0.622 & 0.878 & 0.862 & 0.870 & 0.890 \\
\hline
\end{tabular}

${ }^{a} \mathrm{GD}$ : gene diversity, ${ }^{\mathrm{b}} \mathrm{PIC}$ : polymorphism information contents, ${ }^{\mathrm{c}} \mathrm{PE}$ : power of exclusion, and ${ }^{\mathrm{d}} \mathrm{PD}$ : power of discrimination.

ranged from 0.114 at PS27 (Sorea) to 1.000 at several loci and 0.815 at PS704 (Taean) to 0.900 at several loci, respectively. The polymorphism information contents (PIC) was also very high ranging from 0.800 at PS108 (Taean) to 0.940 at PS704 (Yeonpyeong-do Island). Microsatellites are usually called highly informative loci, if the PIC values are higher than 0.7 .

\section{Discussion}

The swimming crab, $P$. trituberculatus is one of the most important fishery resources in the East Asian countries. However, the population genetic structure of this species was less understood at the molecular level. Although several molecular phylogenetic analyses have been taken, most studies have been performed on the mtDNA polymorphisms $[5,9,11,23]$, and fewer studies were done for microsatellite loci $[6,10,24]$.

The present study identified 52 polymorphic microsatellite loci. Of them, 10 hypervariable loci were chosen, and were examined for their polymorphism and phylogenetic analysis of four $P$. trituberculatus populations. The genotyping results revealed that all the analyzed loci were highly informative for four examined populations with high level of the PIC $(\geq 0.7)$. The mean number of alleles per locus, PIC, observed and expected hetrozyosities were 69.5, 0.881, 0.762 and 0.916 , respectively. The PD and PE, which are important indexes for individual identification and paternity examination, also showed high values with means of 0.863 and 0.677 , respectively. The high polymorphism found in this study is most likely due to the large number of alleles found in P. trituberculatus. Besides, most microsatellite loci are dinucleotides, which typically show higher levels of polymorphism [7]. The number of alleles per locus is positively correlated with the number of repeat motifs $[4,7]$.

Significant deviations of the Hardy-Weinberg equilibrium (HWE) were detected in three loci in Yeonggwang, five loci in Taean, eight loci in Sorea, and two loci in Yeonpyeong-do Island population. The observed heterozygosities in four populations were significantly lower than the heterozygosity expected value, especially in Taean and Sorea populations. Similarly, previous study for Wonsando Island and Jeonjangpo $P$. trituberculatus populations also showed deviations from HWE in many loci [10]. The departure from HWE in several loci may due to small sample sizes and hyper-polymorphisms, as well as heterozygote deficiency by null alleles, stuttering or large allele dropout [17].

The genetic differentiation ( $F$ st value) showed less than 0.05 (range 0.0020-0.0124), therefore, we suggested that four groups of $P$. trituberculatus were considered to indicate little genetic differentiation. We also confirmed this suggestion from the phylogenetic analysis. We could not find any statistically significant geographical structure from a neighbor-joining tree, in which there is no apparent relationship between the location where a given sample was located and its genetic relationship with the other samples. The high level of genetic diversity and little genetic differentiation between populations may reflect active gene flow among the Yellow Sea populations of $P$. trituberculatus. The low genetic differentiation of $P$. trituberculatus is consistent with other studies. The mtDNA haplotype study also suggested that three $P$. trituberculatus groups from the Korean side of the Yellow Sea have no significant geographical structure [5]. Populations of $P$. trituberculatus in the East China Sea and 
in the Korean Yellow Sea also revealed low genetic differentiation between the populations from the F-statistic analysis using microsatellites $[10,24]$. The swimming crab, $P$. trituberculatus in the Yellow Sea may go on an excursion with a long migration track.

Because swimming crab is a commercially very important fishery resource, more than 10 million young crabs are stocked in the Yellow Sea in each year, to increase the amount of catch in Korea. However, the economic and ecological effects of crab stocking have not been exactly determined. Several forensic parameters indicated that the examined loci are suitable for individual identification and paternity test, thus the developed microsatellite loci may be available for determination of stocking effect by a maternity test between parent (female) and recaptured crabs. Although this study did not examine the cross-species amplification, the developed loci may be applicable to other related species, since several $P$. trituberculatus microsatellites have been applied in two other portunid species, $P$. pelagicus and $P$. sanguinolentus [24]. Altogether, we consider that these highly polymorphic microsatellite markers will provide a useful tool for the population structure and ecogenetic studies as well as management of swimming crab, $P$. trituberculatus.

\section{Acknowledgements}

This study was supported by the Korea Fisheries Resources Agency (FIRA), Ministry for Food, Agriculture, Forestry and Fisheries, and the National Research Foundation (NRF) grant funded by the Ministry of Education (2011-0013694), Republic of Korea.

\section{References}

1. An, H. S., Lee, J. H., Noh, J. K., Kim, H. C., Park, C. J., Min, B. H., and Myeong, J. I. 2010. Ten new microsatellite markers in cutlassfish Trichiurus lepturus derived from an enriched genomic library. Anim Cells Sys 14, 169-174.

2. Blouin, M. S., Parsons, M., Lacaille, V. and Lotz, S. 1996. Use of microsatellite loci to classify individuals by relatedness. Mol Ecol 5, 393-401.

3. Bowman, T. E. and Abele, L. G. 1982. Classification of the recent Crustacea, pp. 1-92. In: Vol. 1: Systematics, the Fossil Record, and Biogeography, L.G. Abele (ed.), The Biology of Crustacea. Academic Press, New York, NY.

4. Brandstrom, M. and Ellegren, H. 2008. Genome-wide analysis of microsatellite polymorphism in chicken circumventing the ascertainment bias. Genome Res 18, 881-887.

5. Cho, E. M., Min, G. S., Kanwal, S., Hyun, Y. S., Park, S.
W. and Chung, K. W. 2009. Phylogenetic analysis of mitochondrial DNA control region in the swimming crab, Portunus trituberculatus. Anim Cells Sys 13, 305-314.

6. Cui, Z., Liu, Y., Wang, H., Wu, D., Luan, W., Tan, F. and Huang, M. 2012. Isolation and characterization of microsatellites in Portunus trituberculatus. Conservation Genet Resour 4, 251-255.

7. Ellegren, H. 2004. Microsatellites: simple sequences with complex evolution. Nat Rev Genet 5, 435-445.

8. Goldstein, D. B., Linares, A. R., Cavalli-Sforza, L. L. and Feldman, M. W. 1995. An evaluation of genetic distances for use with microsatellite loci. Genetics 139, 463-471.

9. Imai, H., Fujii, Y. and Karakawa, J. 1999. Analysis of the population structure of the swimming crab, Portunus trituberculatus in the coastal waters of Okayama Prefecture, by RFLPs in the whole region of mitochondrial DNA. Fish Sci 65, 655-656.

10. Lee, H. J., Lee, D. H., Yoon, S. H., Kim, D. H., Kim, S. G., Hyun, Y. S., Min, G. S. and Chung, K. W. 2013. Characterization of 20 microsatellite loci by multiplex PCR in swimming crab, Portunus trituberculatus. Genes Genom 35, 77-85.

11. Liu, Y., Liu, R., Ye, L., Liang, J., Xuan, F. and Xu, Q. 2009. Genetic differentiation between populations of swimming crab Portunus trituberculatus along the coastal waters of the East China Sea. Hydrobiologia 618, 125-137.

12. Madsen, B. E., Villesen, P. and Wiuf, C. 2010. Short tandem repeats and genetic variation. Methods Mol Biol 628, 297-306.

13. Rice, W. R. 1989. Analyzing tables of statistical tests. Evolution 43, 223-225.

14. Rohlf, F. J. 2002. NTSYSPC: Numerical Taxonomy System, ver. 2.1. Exeter Publishing, Ltd. Setauket, New York.

15. Rousset, F. 2008. GENEPOP'007: a complete re-implementation of the GENEPOP software for Windows and Linux. $\mathrm{Md}$ Ecol Resour 8, 103-106.

16. Schuelke, M. 2000. An economic method for the fluorescent labeling of PCR fragment. Nat Biotechnol 18, 233-234.

17. Sekino, M., Hara, M. and Taniguchi, N. 2002. Loss of microsatellite and mitochondrial DNA variation in hatchery strains of Japanese flounder Paralichthys olivaceus. Aquaculture 213, 101-122.

18. Suji, K. K., Biji, K. R., Poornima, R., Prince, K. S., Amudha, K., Kavitha, S., Mankar, S. and Babu, R. C. 2012. Mapping QTLs for plant phenology and production traits using Indica rice (Oryza sativa L.) lines adapted to rainfed environment. Mol Biotechnol 52, 151-160.

19. Tanksley, S. D., Grandillo, S., Fulton, T. M., Zamir, D., Eshed, Y., Petiard, V., Lopes, J. and Beck-Bunn, T. 1996. Advanced backcross QTL analysis in a cross between an elite processing line of tomato and its wild relative $L$. pimpinellifolium Theor Appl Genet 92, 213-224.

20. Tautz, D. 1989. Hypervariability of simple sequences as a general source for polymorphic DNA markers. Nucleic Acids Res 17, 6463-6471.

21. van Oosterhout, C., Hutchinson, W. F., Wills, D. P. M. and Shipley, P. 2004. MICRO-CHECKER: software for identifying and correcting genotyping errors in microsatellite data. 
Mol Ecol Notes 4, 535-538.

22. Weir, B. S. and Cockerham, C. C. 1984. Estimating F-statistics for the analysis of population structure. Evolution 38, 1358-1370.

23. Xu, Q., Liu, R. and Liu, Y. 2009. Genetic population structure of the swimming crab, Portunus trituberculatus in the East China Sea based on mtDNA 16S rRNA sequences. $J$ Exp Mar Biol Ecol 371, 121-129.

24. Xu, Q. and Liu, R. 2011. Development and characterization of microsatellite markers for genetic analysis of the swimming crab, Portunus trituberculatus. Biochem Genet 49, 202212.

25. Yoo, S. Y., Cho, N. S., Park, M. J., Seong, K. M., Hwang, J. H., Song, S. B., Han, M. S., Lee, W. T. and Chung, K. W. 2011. A large population genetic study of 15 autosomal short tandem repeat loci for establishment of Korean DNA profile database. Mol Cells 32, 15-19.

초록 : 서해안에서 채집된 꽃게(Portunus trituberculatus) 집단에 대한 microsatellite 좌위의 분석

이혜진 ${ }^{1} \cdot$ 윤성종 ${ }^{2} \cdot$ 현영세 $^{1} \cdot$ 김혜진 $^{1} \cdot$ 황성일 $^{3} \cdot$ 배주승 ${ }^{4} \cdot$ 정기화 ${ }^{1}{ }^{4}$

( ${ }^{1}$ 공주대학교 생명과학과, ${ }^{2}$ 국방조사본부, ${ }^{3}$ 수산자원관리공단 자원경제실, ${ }^{4}$ 수중생태기술연구소, ${ }^{5}$ 인천시청 수산자 원팀)

꽃게(Portunus trituberculatus)는 세계적으로 넓게 분포하는 갑각류로 모래나 돌멩이가 있는 해저에 서식한다. 본 연구는 서해의 4 개 지점(영광, 태안, 소래, 연평도)에서 채집된 P. trituberculatus 281 개체에 대해 10 종류 microsatellite 좌위의 유전적 다형성을 조사하였다. 좌위당 대립유전자 수는 50-129개로 평균 69.5개였으며, 관측 및 예상 이형접합도는 각각 0.111-1.000 및 0.609-0.979 범위에 있었다. 좌위별 근친계수((Fis)는 -0.0207에서 0.8175 범 위였다. 유전적 분화도 $(F \mathrm{st})$ 는 0.05 보다 낮게 나타났는데, 이것은 4 꽃게 간의 유전적 분화(genetic differentiation) 가 매우 낮은 이루어진 것으로 추정하게 한다. UPGMA을 이용한 계통도 작성에서도 4 그룹 간의 유전적 거리는 매우 가깝다는 결과를 얻을 수 있었다. 매우 높은 다형성과 집단간의 낮은 유전적 분화는 서해안의 꽃게 집단은 활발한 유전적 흐름(gene flow)이 일어나며, 그룹간 지리적 경계가 없음을 제시한다. 